\title{
Correction to: Running out of steam? A political incentive perspective of FDI inflows in China
}

\author{
Danqing Wang ${ }^{1}$, Zhitao Zhu $^{2}$, \\ Shuo Chen ${ }^{3}$ and \\ Xiaowei Rose Luo $^{4}$

\footnotetext{
${ }^{1}$ The Hong Kong University of Science and Technology, Hong Kong, China; ${ }^{2}$ The Chinese University of Hong Kong, Hong Kong, China; ${ }^{3}$ Fudan University, Shanghai, China; ${ }^{4}$ INSEAD, Fontainebleau, France
}

\section{Correspondence:}

D Wang, The Hong Kong University of Science and Technology, Hong Kong, China e-mail: danqingw@ust.hk
Journal of International Business Studies (2022) 53, 375-376. https://doi.org/10.1057/s41267-02 1-00436-z

\section{CORRECTION TO: JOURNAL OF INTERNATIONAL BUSINESS STUDIES (2020) HTTPS://DOI.ORG/10.1057/S41267-020- 00366-2}

The article Running out of steam? A political incentive perspective of FDI inflows in China, written by Danqing Wang, Zhitao Zhu, Shuo Chen and Xiaowei Rose Luo, was originally published electronically on the publisher's internet portal on 27 September 2020 without open access. With the author(s)' decision to opt for Open Choice the copyright of the article changed on 4 April 2021 to (c) The Author(s) 2021 and the article is forthwith distributed under a Creative Commons Attribution 4.0 International License, which permits use, sharing, adaptation, distribution and reproduction in any medium or format, as long as you give appropriate credit to the original author(s) and the source, provide a link to the Creative Commons licence, and indicate if changes were made. The images or other third party material in this article are included in the article's Creative Commons licence, unless indicated otherwise in a credit line to the material. If material is not included in the article's Creative Commons licence and your intended use is not permitted by statutory regulation or exceeds the permitted use, you will need to obtain permission directly from the copyright holder. To view a copy of this licence, visit http://creativecommons.org/licenses/by/4.0.

\section{OPEN ACCESS}

This article is licensed under a Creative Commons Attribution 4.0 International License, which permits use, sharing, adaptation, distribution and reproduction in any medium or format, as long as you give appropriate credit to the original author(s) and the source, provide a link to the Creative Commons licence, and indicate if changes were
The original article can be found online at https://doi.org/10.1057/s41267-020-00366-2.

Online publication date: 18 June 2021 
made. The images or other third party material in this article are included in the article's Creative Commons licence, unless indicated otherwise in a credit line to the material. If material is not included in the article's Creative Commons licence and your intended use is not permitted by statutory regulation or exceeds the permitted use, you will need to obtain permission directly from the copyright holder. To view a copy of this licence, visit http://creativecommons.org/licenses/ by $/ 4.0 /$.

Publisher's Note Springer Nature remains neutral with regard to jurisdictional claims in published maps and institutional affiliations. 